Ife Journal of Science vol. 20, no. 3 (2018)

\title{
PETROLOGICAL AND STRUCTURAL INVESTIGATION OF ROCKS AROUND IGARRA, SOUTHWESTERN NIGERIA
}

\author{
Ogbe, O.B. ${ }^{1}$, Olobaniyi, S.B. ${ }^{2}$, Ejeh, O.I. ${ }^{3}$, Omo-Irabor, O.O. ${ }^{1}$, Osokpor, J. ${ }^{1}$, Ocheli, A. ${ }^{4}$ and \\ Overare, B. ${ }^{1}$ \\ ${ }^{1}$ Department of Earth Sciences, Federal University of Petroleum Resources, Effurun \\ ${ }^{2}$ Department of Geosciences, University of Lagos, Lagos \\ ${ }^{3}$ Department of Geology, Delta State University, Abraka \\ ${ }^{4}$ Department of Geological Sciences, Nnamdi Azikiwe University, Awka \\ *Corresponding author: ogbe.ovie@fupre.edu.ng \\ (Received: 21st February, 2018; Accepted: 10th October, 2018)
}

\section{ABSTRACT}

Structural mapping and petrographic study carried out on the exposed Basement rocks of Igarra area, Southwestern Nigeria, have been used to infer the metamorphism, evolution and deformation history prevalent in the Igarra schist belt. The rocks exposed in the Igarra schist belt are mainly metasediments and intrusives. The metasediment comprises of inter-bedded quartz-biotite schist and minor bodies of quartzite, metaconglomerate, quartz-sericite schist and marble. The intrusives which cross-cut the metasediments in places consist of porphyritic-granite, aplite/pegmatite, syenite and subsidiary quartz vein. Petrographic analysis study involved megascopic and microscopic studies of structures in the rocks, while structural analysis entailed field based measurements and stereographic plots of structural elements of the metasediments. Two phases of metamorphism and deformation were inferred from two generations of foliation, $\mathrm{S}_{1}$ and $\mathrm{S}_{2}$ in that order. Metamorphic facies defined by index minerals assemblage indicated a low to medium grade metamorphism. Structural analysis of field data reveals a NNW-SSE trending foliation $\mathrm{S}_{2}$ that cut across an earlier foliation $\mathrm{S}_{1}$, generally in a N-S direction and a tight to isoclinal anticline plunge fold of the metasediments. The evolution of this belt can be related to sedimentary piles that were deformed and metamorphosed as a result of tectonic activities during the Paleoproteozoic and Neoproterozoic times, followed by the intrusion of granitoids and subsequent erosion and weathering of the rocks to produce the present topography.

Keywords: Metasediments, petrography, metamorphism, structural mapping, Igarra, southwestern Nigeria.

\section{INTRODUCTION}

The Nigerian schist belts are a part of the Basement Complex that comprised of other rock suites such as the migmatite-gneiss complex that was intruded by the Pan-African Granites (Figure 1). The metasediments occur as supracrustal cover on the basement and consists of quartzite, metaconglomerate, mica-schist and marble (Okeke and Meju, 1985; Ajibade et al., 1987;
Imeokparia and Emofurieta, 1991). The Igarra metasedimentary belt is a prominent schist belt located in the southwestern part of Nigeria (Figure 1). The schist belt occurs as N-S trending zone of low to medium grade metasediments such as phyllite, semi-pelitic to pelitic schist, metagreywacke, metaconglomerate, quartzite and basic to ultrabasic metavolcanics (Rahaman, 1988; McCurry, 1989; Annor, 1998). 


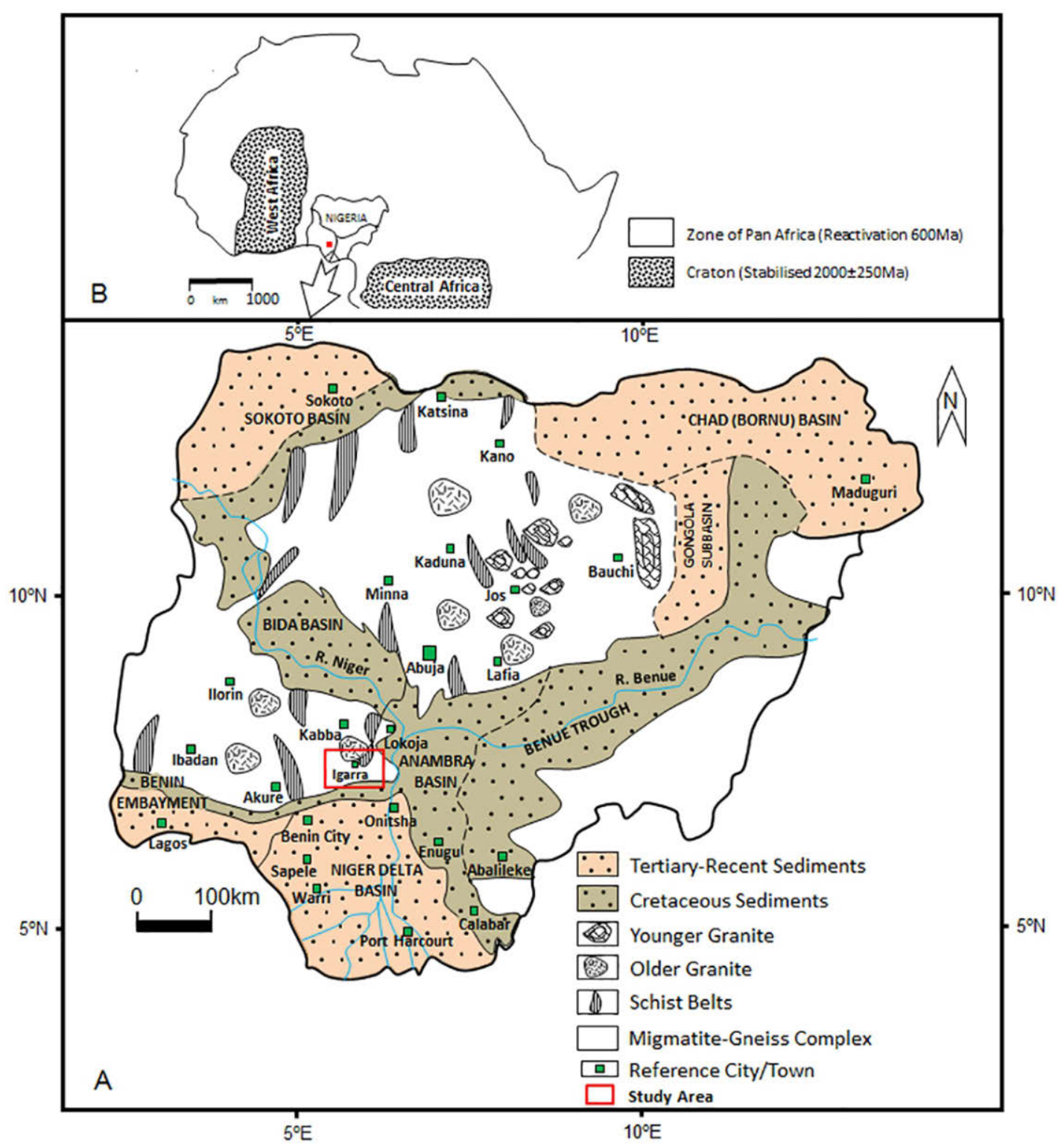

Figure 1 Simplified geologic map of Nigeria showing the study area (A). Inset is the map of Nigeria within the African shield (B)

Odeyemi (1976) classified the basement rocks around Igarra into three groups, namely migmatite-gneiss complex, low grade metasediments and granitoids. The foliations exhibited by the basement rocks of southwestern Nigeria with the exception of the intrusives are tectonic in origin (Odeyemi, 1988). Boesse and Ocan (1992) reported that the belt has been affected by two phases of orogeny (deformation): the first phase $\left(\mathrm{D}_{1}\right)$ produced tight to isoclinal folds with north-southerly direction while the second phase $\left(D_{2}\right)$ that was characterized by more open folds of variable style with large vertical NNESSW trending fault. Fractures ranging from minor (joints) to major ones were ubiquitous among the metasediments and the intrusives, some of which were filled by quartz veins trending generally in NE-SW direction.

Although the age of the schist belts has been a subject of debate, Ogezi (1977) obtained a Neoproterozoic (Pan-African) and this age was confirmed by Ajibade et al. (1989) using Rb/Sr isochron which gave $556 \pm 16 \mathrm{Ma}$ for phyllites from the Birnin-Gwari belt. This age was interpreted as too young to represent the age of metamorphism but instead reflects a later heating event related to the Older Granite activity during the Pan-African (Annor, 1998). Holt (1982) also obtained Rb/Sr 
isochron age of $750 \mathrm{Ma}$ on micro-tonalites which are interlayered with the metasedimentary rocks of the Anka belt and were involved in the first deformation of the sediments. This indicates the possibility of early Pan-African sedimentation and volcanism in the belt. Annor (1995) suggested Paleoproterozoic age $(2103 \pm 8 \mathrm{Ma})$ based on $\mathrm{U}-\mathrm{Pb}$ Zircon dating of cross-cutting granodiorite-gneiss with mica schist xenoliths in the Kabba area. Paleoproterozoic age was also suggested by Olobaniyi (2003) based on the close association of the schist of the Isanlu area (Egbe-Isanlu schist belt) with talc schist and banded iron formation that are regarded as markers for the early Precambrian. However, Oyinloye (2006) on the basis of U-Pb zircon (monazite) model dating suggested $2750 \pm 25 \mathrm{Ma}$ (Archean age), this buttresses the isotopic evidence of PreNeoproterozoic age that was hitherto suggested by Annor (1995).

Establishing the contact relationships between the metasediments and the intrusives can be quite challenging, due to migmatisation, complex structural patterns, with some areas that are largely masked by thick overburden of recent sedimentary materials. Despite the aforementioned limitations, this work is an attempt to map rock boundaries and the field relationships between the various rock types in the area of study, interpret the sequence of geologic events of the belt and produce a geological map of the study area.

\section{GEOLOGY OF STUDY AREA}

The Igarra schist belt is located in the southwestern segment of the Precambrian Basement Complex of Nigeria (Figure 1). The study area (about 230 $\mathrm{km}^{2}$ ) is delimited by latitudes $07^{\circ} 15^{\prime}$ to $07^{\circ} 20^{\prime}$ $12^{\prime \prime} \mathrm{N}$ and longitudes $06^{\circ} 00^{\prime}$ to $06^{\circ} 12^{\prime} \mathrm{E}$ (Figure 2). The Older Granite suite is well exposed in scenic hills, while the metasediments occur in plains and low lying areas especially stream channels such as river Onyami. Secondary structural features such as fractures and folds are often ubiquitous.

\section{MATERIALS AND METHODS}

This study involved a geological field mapping of the area on a scale of 1:50,000. Detailed geological field mapping involved the use of relevant tools for measurements of structural features, and representative rock samples were obtained for petrographic analysis. Identification of the various rock types was based on their lithological properties. Both identified rock types and readings of structural features are plotted on a base map. Data (about 100 readings of strike and dip) obtained from the measurement of structural features recorded at outcrop locations in the field were analyzed statistically and plotted using equalarea net and Rose diagrams. Pi $(\pi)$ and Beta $(\beta)$ diagrams on equal-area net generally expressed as lower hemisphere contoured stereogram were plotted to represent structural trend and inferred the tectonic stresses that affected the belt. Megascopic and microscopic petrographic descriptions of the rocks were done in the field and the laboratory respectively.

\section{FIELD AND PETROGRAPHIC DESCRIPTION}

\section{Field Relationships and Lithologies}

The area study consists of two main suites of rocks: the host metasedimentary suite made up of quartz-biotite-schist, mica-schist, quartz-sericite schist, quartzite, metaconglomerate, calc-silicategneiss and marble and the intrusive suite comprising of porphyritic-granite, aplite/Pegmatite and syenites.

\section{Metasedimentary Suite}

The host metasedimentary suites are low-lying while the Pan African intrusives constitute the higher topography, a common scenic feature observable in the area. This is a reflection of the greater susceptibility of the metasediments to prolonged weathering and erosion than the younger intrusives which are more resistant to weathering and erosion. Metaconglomerate, quartzite, marble and calc-silicate gneiss are concordantly inter-banded with quartz-biotite schist. This is probably an indication that the protoliths such as carbonate and very fine-grained clastic sediments were subjected to similar thermotectonic event. Outcrops of calc-silicate gneiss are often low-lying between metaconglomerate and quartz-biotite schist. 


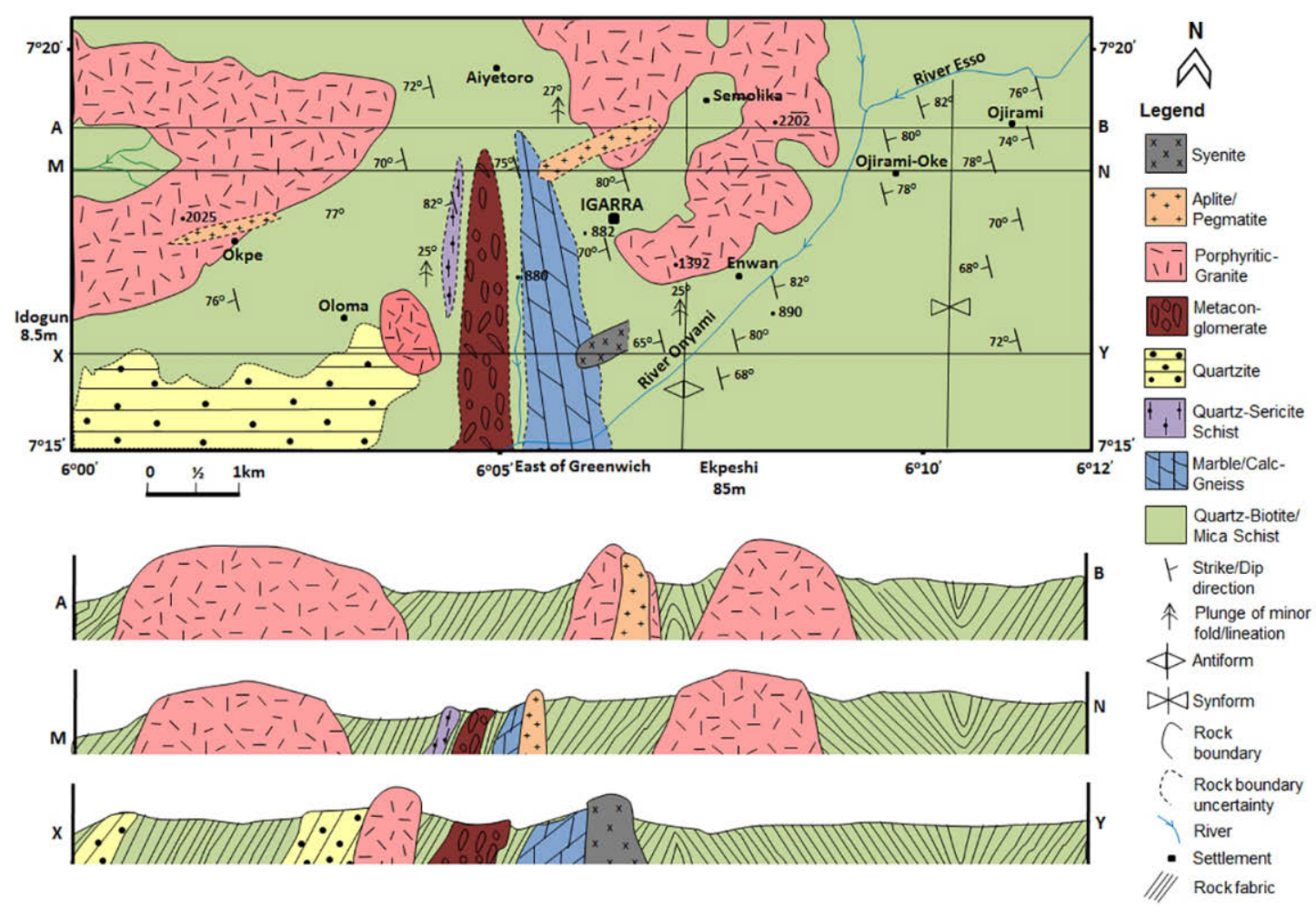

Figure 2: Geological map of Igarra and surrounding areas with cross sections indication lines of section $\mathrm{AB}, \mathrm{MN}$ and $\mathrm{XY}$.

Quartz-biotite Schist: This is the dominant rock unit in the study area. It occurs as low-lying foliated outcrops within the area (Figure 2). Dark grey bands contain biotite marked by flaggy parting, whereas the light grey bands contain quartz and feldspar of very fine-grain granulitic texture. A thin band of quartz-sericite schist was found to be associated with the quartz-biotite schist. This rock is often associated with quartz vein (Figure 3).

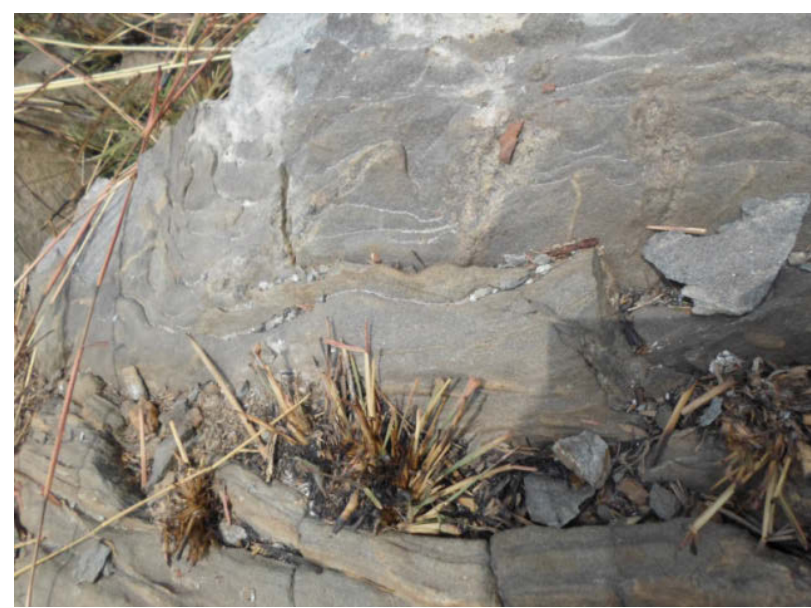

Figure 3: Quartz-biotite schist outcrop, from $1 \mathrm{~km}$ east of Aiyetero.
In thin sections quartz-biotite schist is mainly composed of fine-grained quartz (Qtz) and biotite (Bio). Quartz exhibits granulitic texture and biotite revealed foliation in form parallel mineral alignment within the rock. The biotite shows pleochroic scheme, $\mathrm{X}=$ amber; $\mathrm{Y}$ and $\mathrm{Z}=$ greenish brown. Inclusions of zircons (Zirc) as accessory minerals are haloed. Minor minerals, Plagioclase (Plag) and microcline (Micr) present form a granulitic texture with quartz (Figure 4). Muscovite (Musc) is less oriented than the biotite that occurs as ragged and inter-leave with the biotite (Figure 4). Accessory mineral include zircon, epidote (Epi) and sphene (Sphe). 

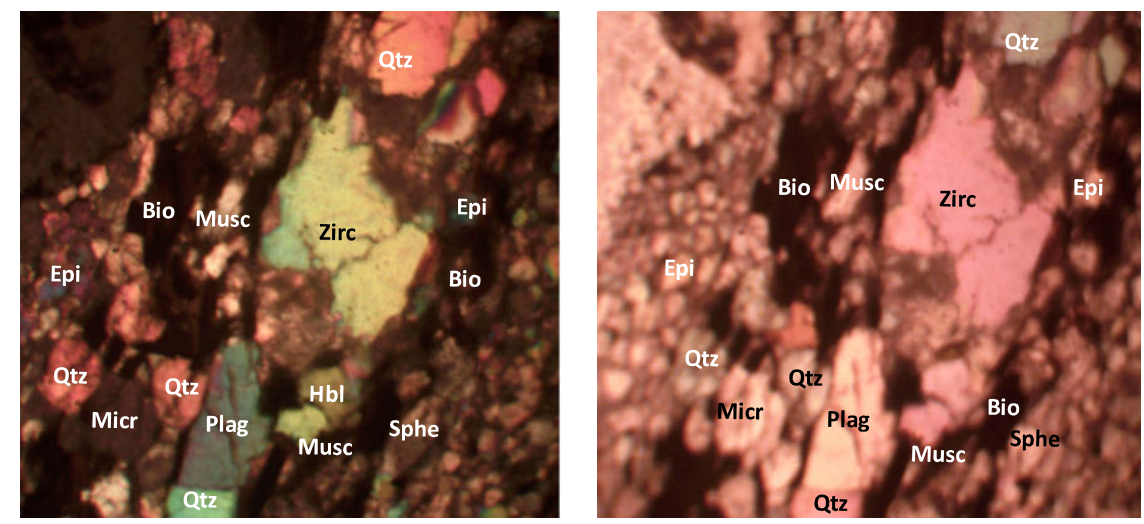

Figure 4: Thin section photomicrographs of quartz-biotite schist (Magnification: 40x). (a) Under crosspolarised light. (b) Under plane-polarised light.

Metaconglomerate: Metaconglomerate occur within the quartz-biotite schist (Figure 2) and trends in a north-south manner, although poorly exposed. The grain shapes are sub-rounded to rounded or stretched (Figure 5). Although the rock is nonfoliated, the stretched pebbles showed a definite lineation which is related to orientation of paleostress.

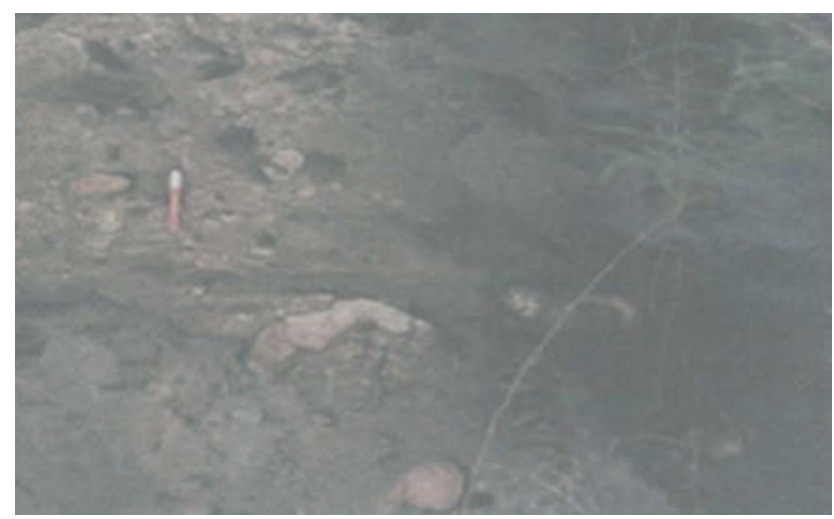

Figure 5: Metaconglomerate outcrop, behind Success Group of School, Igarra Town.

In thin sections metaconglomerate is essentially hornblende ( $\mathrm{Hbl})$, epidote and chlorite $(\mathrm{Cl})$ appear composed of quartz, plagioclase feldspar and as minor minerals (Figure 6). The chlorite appears biotite (Figure 6). The quartz exhibits granulitic dark-green to brown whilst the hornblende texture. The biotite shows characteristic amber to dark-brown coloured pleochroism. Muscovite,

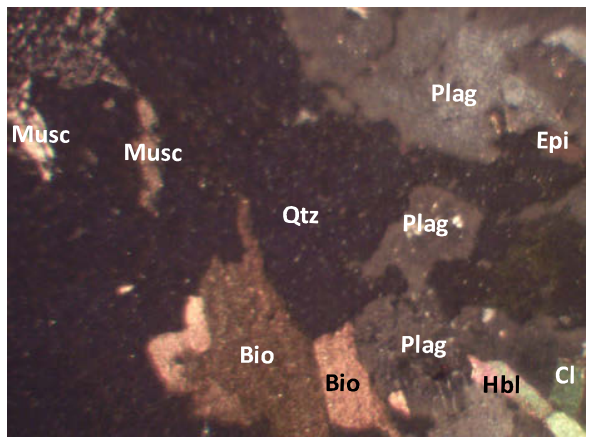
appears light green to pale-brown on rotation.

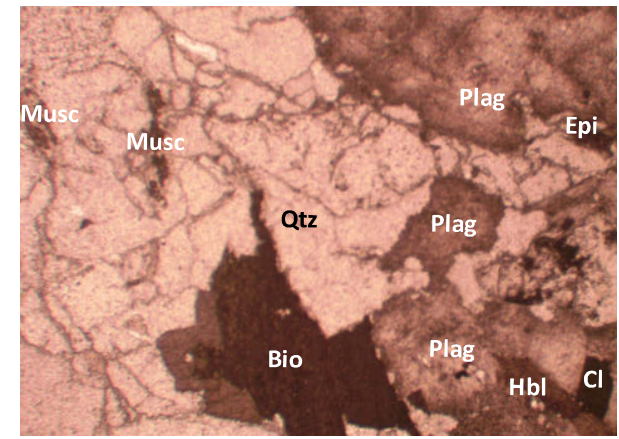

Figure 6: Thin section photomicrographs of metaconglomerate (Magnification: 40x). (a) Under crosspolarised light (b) Under plane-polarised light. 
Quartz-sericite schist: Quartz-sericite schist is also low-lying and exposed in an excavated site along the Igarra-Okpe road (Figure 7). On an outcrop scale, it occurs as a narrow band within the quartzbiotite schist with steeply dipping foliations $\left(72^{\circ}-\right.$ $80^{\circ}$ ) (Figure 2). Schistocity in this rock resulted from parallel orientation of platy minerals such as mica which creates a definite zone of weakness, allowing the rock to break along nearly parallel planes. The rock appears to have been weathered though (Figure 7).

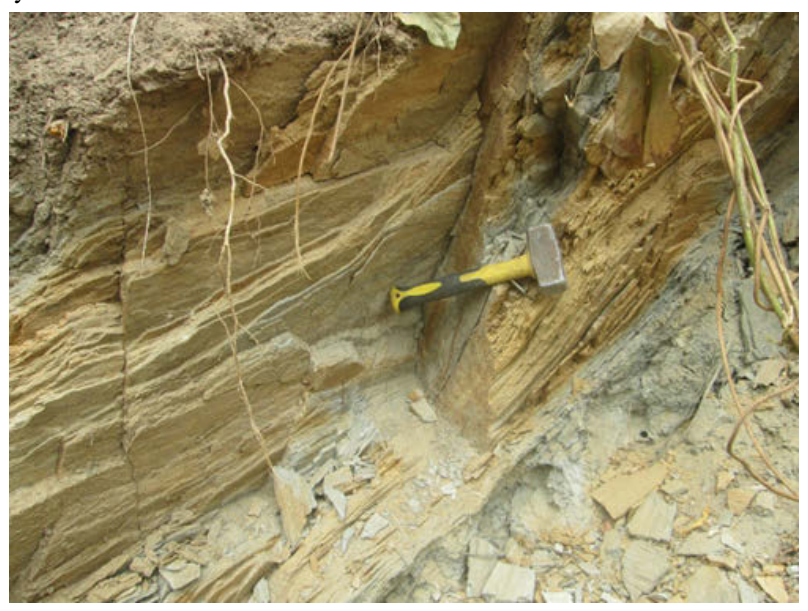

Figure 7: Exposed section of quartz-sericite schist, $2 \mathrm{~km}$ from Okpe junction at Igarra, along Igarra-Okpe road

Marble and Calc-Silicate-Gneiss: Exposures of marble and calc-silicate gneiss showed sharp but concordant contact relationship with quartzite and quartz-biotite schist (Figures 2 and 8). Marble is non-foliated with interlocking crystals, dominated by calcite with minor amount of quartz. It appears white and dark-grey in colour with sharp contacts in different portion of an outcrop (Figure 8). The whitish marble is made up of more coarse-grained crystals than the darkgrey marble. The dark-grey marble appears to contain minor amount of biotite.
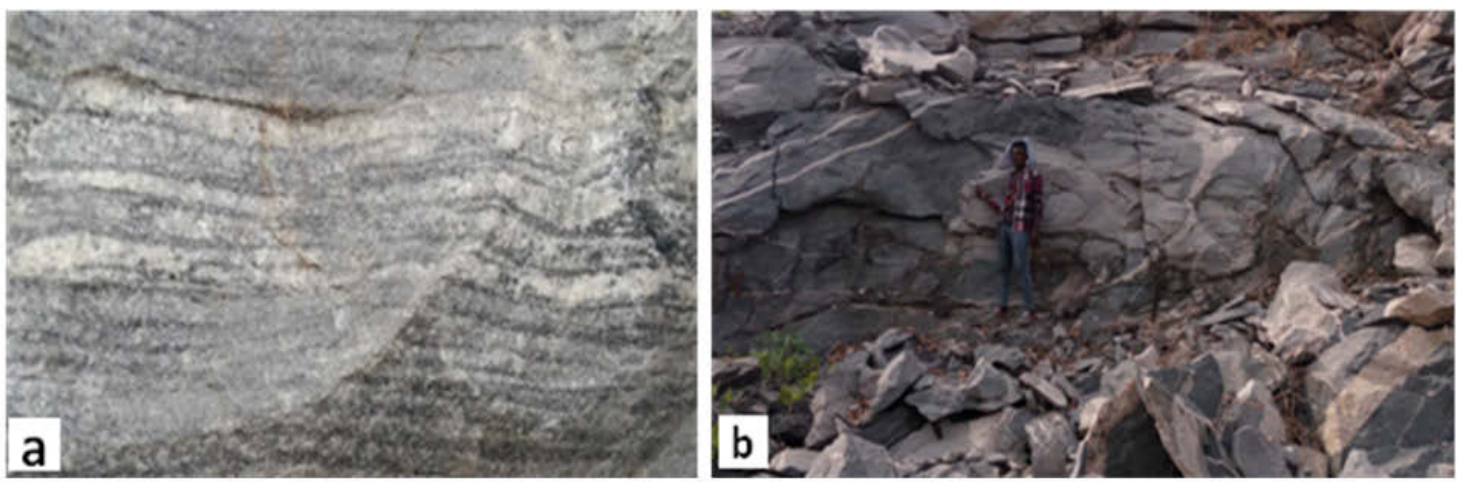

Figure 8: Outcrop sections of (a) Calc-silicate gneiss, along Igarra-Okpe road. (b) Marble from about $1.4 \mathrm{~km}$ south of Igarra Town.

The calc-silicate gneiss is fine to coarse grained with interlocking crystals. It is foliated rock, marked by layering of different mineral groups (Figures 2 and 5). The foliation is depicted by semi-continuous layers of light and dark minerals to highly contorted or well defined layers.

In thin section calc-silicate gneiss is composed of quartz, biotite, calcite (Calc) with minor amounts of microcline and hornblende. Quartz occurs as fine-grained granulitic texture. The dark bands are essentially composed of biotite and hornblende. Biotite shows pleochroic scheme, $\mathrm{X}=$ light yellow; $\mathrm{Y}$ and $\mathrm{Z}=$ brown, forms fine crystals, and hornblende shows pleochroic scheme, $Z=$ dark green, $\mathrm{X}$ and $\mathrm{Y}=$ very light green. Quartz and 
anhedral calcite dominate the lighter bands and the calcite shows signs of recrystallisation that resulted to larger grains and display rhombohedra cleavage (Figure 9). Microcline displays cross-

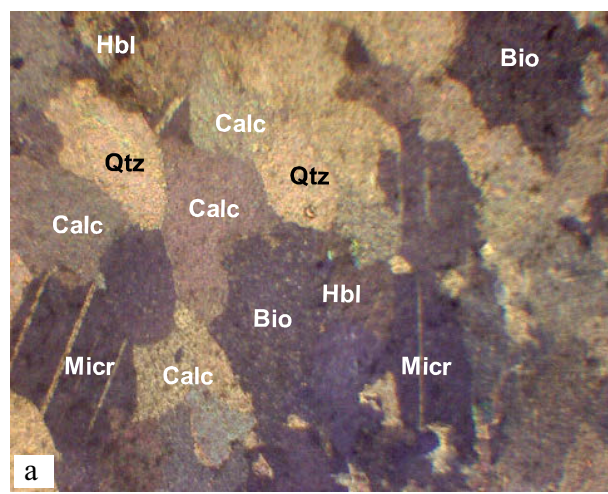

hatched twinning and dirty-green to pinkish colouration (Figure 9). The hornblende appears as yellowish green with set of cleavage.

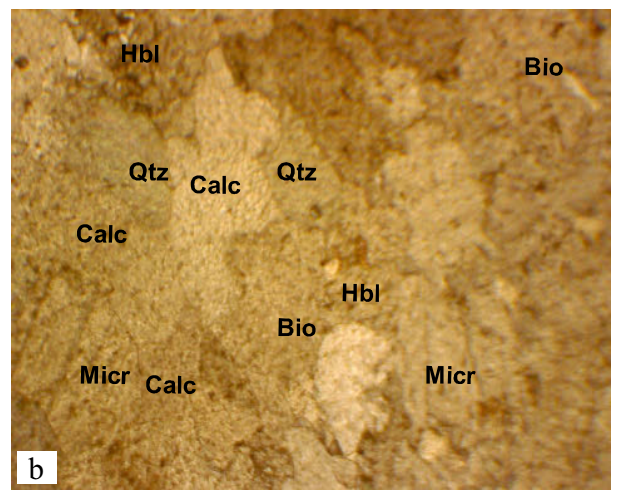

Figure 9: Thin section photomicrographs of cal-silicate gneiss (Magnification: 100x). (a) Under crosspolarised light (b) Under plane-polarised light.

Quartzite: Quartzite is non-foliated, with quartz as the dominant mineral and some impurities which gives it a characteristic brownish colouration. Individual grains in the quartzite are deformed, inter locked, so the rock fractures indiscriminately.
A quartzite ridge occurred in the southwestern part of the area mapped (Figure 2) and can be seen as collection of fractured cobbles and boulders (Figure 10a).
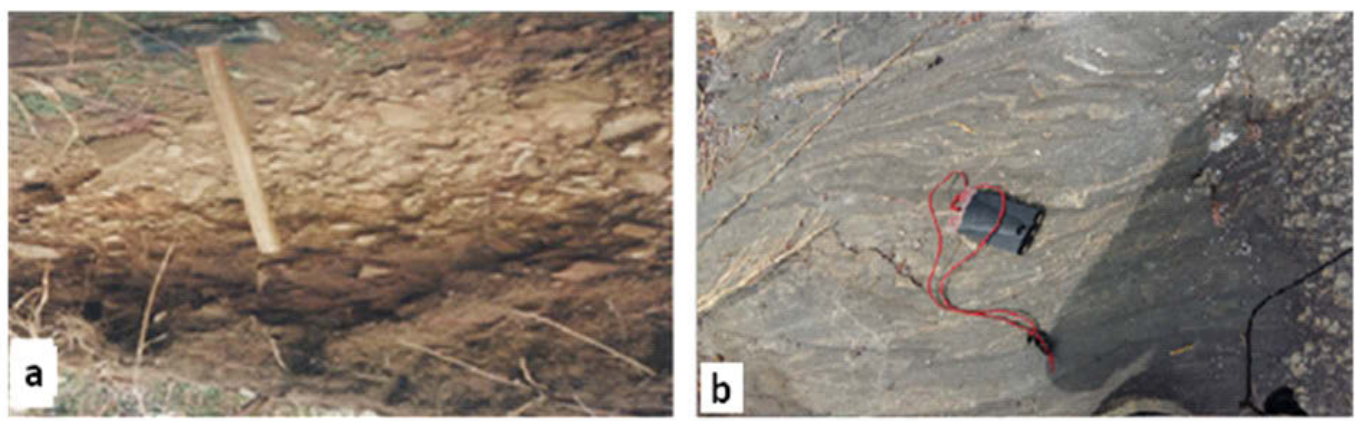

Figure 10: Outcrop sections of (a) Quartzite exposure at Oloma. (b) Quartz-biotite schist in contact with granite at Semolika.

\section{Intrusives}

These suites of rocks intrude the metasedimentary rocks. They consist dominantly of porphyritic granite and others such as syenite, aplite/pegmatite and quartz vein. Xenoliths of metasediments (gneiss and schist) found in some of the intrusive rocks are indications of magmatic stopping and inclusion. However, porphyritic granite seems to be the oldest among the intrusives, followed by aplite/pegmatite and quartz veins (Figure 2). Syenite occurs as discordant, unmetamorphosed dykes and is believed to be the youngest of all (Odeyemi, 1976). The intrusives are found in the west and central part of the study area (Figure 2).

Porphyritic granite: This rock generally occur as massive and high rising outcrops relative to the low lying schist they intrude (Figures 10b and 11a). They are usually coarse to very coarse grained and often phenocrytic (Figure 11b). The rock contains xenoliths of the host metasediments (Figure 11b) and obliquely cuts the penetrative fabric of the later (Figures 2 and $10 \mathrm{~b}$ ). This suggested that, it is younger than the development of the metamorphic structure of the host metasediments. The porphyritic granite is found in the west and central part of the area mapped (Figure 2). 

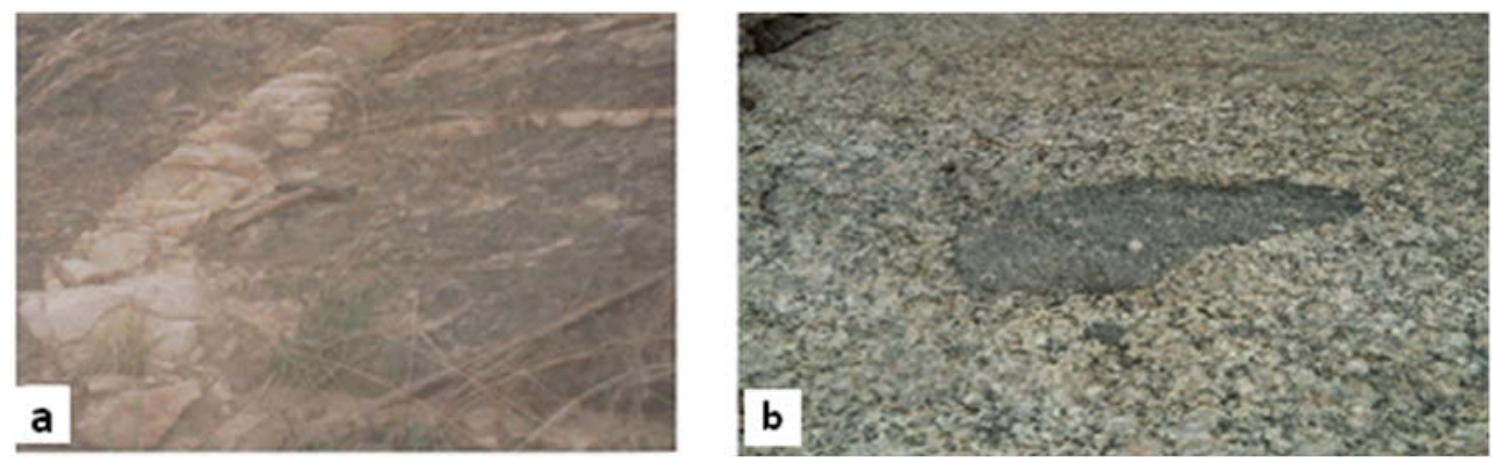

Figure 11: Intrusive suites (a) Quartz vein cross-cutting biotite-schist (1 $\mathrm{km}$ south of Aiyetero). (b) Xenolith in porphyritic-granite $(\approx 1.5 \mathrm{~km}$ southeast of Aiyetero junction).

It is composed essentially of quartz, microcline, plagioclase, biotite and hornblende as minor accessory (Figure 12). Microcline shows a double set of polysynthetic twin and a first order grey to white (Figure 12). Plagioclase shows dark grey parallel twins between crossed polars. Biotite shows pleochroism from brown to pale brown. Hornblende shows yellowish green colouration with two sets of cleavage (Figure 12).
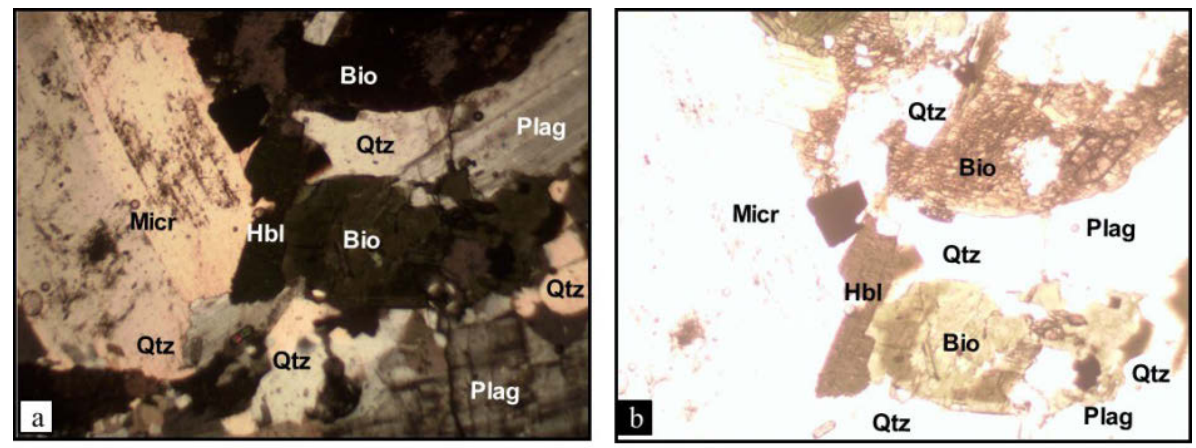

Figure 12: Thin section photomicrographs of porphyitic granite (Magnification: 100x). (a) Under crosspolarised light (b) Under plane-polarised light.

Syenite: Although cross-cutting relationship between syenites and aplite/pegmatite was not mapped, this rock seems to be younger than the aplite/pegmatite. It is made up of dark minerals which gave its black colouration, with traces of light minerals (Figure 13). The outcrops are closely spaced and general trend in the NE-SW direction (Figure 2).

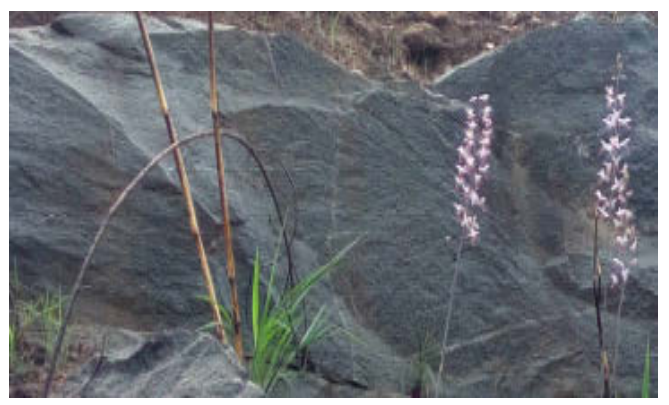

Figure 13: Exposed section of syenite dyke, along Igarra-Auchi road, about $1 \mathrm{~km}$ from Igarra town.

In thin sections syenite shows orthoclase (Orth) with pyroxene (Pyro) form the groundmass minerals of the syenite, pyroxene displays two sets cleavage and shows pale yellow colouration (Figure 14). Other minerals present including hornblende, and minor occurrence of biotite. 

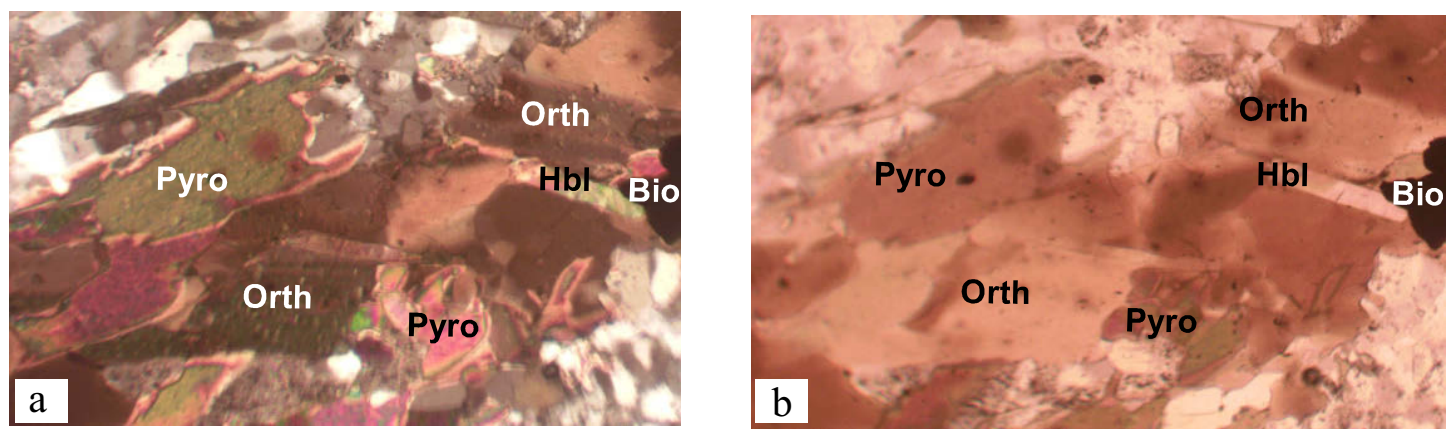

Figure 14: Thin section photomicrographs of metaconglomerate (Magnification: 100x). (a) Under cross-polarised light. (b) Under plane-polarised light.

Aplite/Pegmatite: Aplite occurs as low-lying body, uniformly fine grained and pinkish in colour (Figure 15a). It occurs as thin dyke within coarse grained plutons. Pegmatite occurs with the porphyritic biotite granite as veins cross-cutting

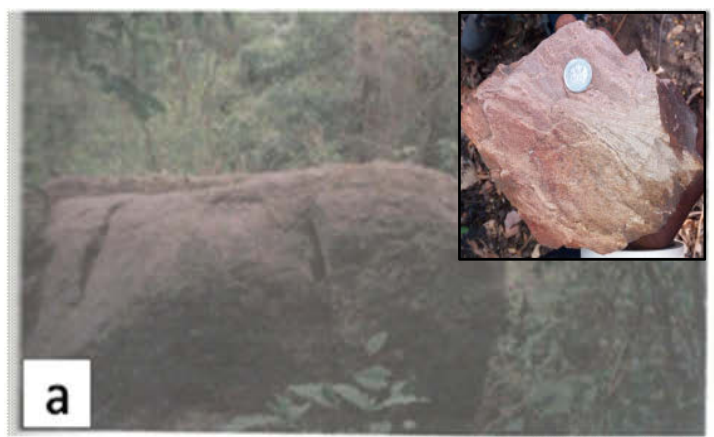

the granite. There is a simple gradation from pegmatite to aplite. The pegmatites are coarse grained in texture (Figure 15b) and composed of mainly feldspars and quartz.

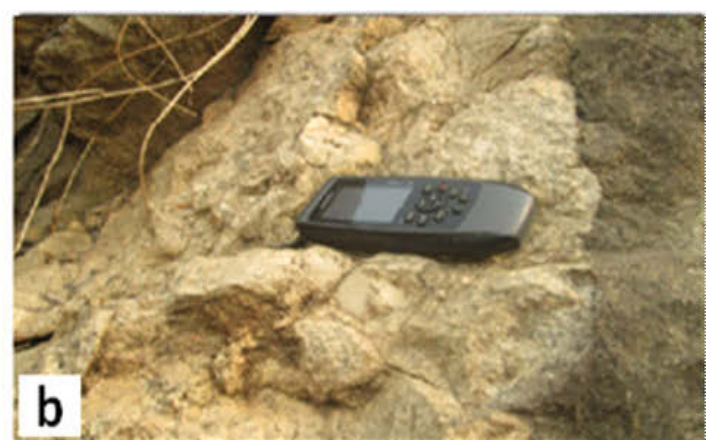

Figure 15: Outcrops of the intrusive (a) Aplite, close to Anglican Cemetery, north of Igarra. Insert, the hand specimen. (b) Pegmatite cutting across porphyritic granite at Okpe.

\section{Structural Geology}

Structural features identified in the area include foliations, lineations, folds and fractures. The strike and dip measurement data obtained from schist outcrops over the entire area defines a tight isoclinal antiform and complimentary synform (Figure 2). Equal-area stereonet plots also revealed that the isoclinal fold plunges at a low angle of 10 $25^{\circ}$ at a bearing of $340^{\circ}-350^{\circ}$ (Figure 16). The $\mathrm{S}_{2}$ foliation that cuts across an earlier $S_{1}$ foliation suggests the effect of a SSE-NNW compressive stress (Figure 16). The $\mathrm{S}_{2}$ structures have been linked to the Pan-African orogeny which superimposed its imprints on the pre-existing structure(s) (Annor et al., 1996).

\section{Foliation and Lineation}

Foliation is the earliest structural element in the area, occurring in the form of lithologic banding, mineralogical banding, and cleavages (schistosity and crenulations). Two foliation trends generally in the NNW-SSE with minor variation in NW-SE and NE-SW direction have been observed in the field that can be related to two phases of deformation of the metamorphic rocks (Figure 16). The earliest foliation which is the $S_{1}$ seems to be parallel to the original sedimentary bedding $S_{0}$. This $S_{1}$ foliation was later transposed by a later deformation episode marked by $\mathrm{S}_{2}$ foliation (Boesse and Ocan, 1992). The $S_{2}$ seems to have been formed during the $F_{1}$ folding phase as an axial planar structure, representing orogenic events (Annor, 1998). Foliation is well defined in schist (Figure 17). Lineation is most common in the metasediments, which exhibits light and dark coloured minerals largely trend NNW-SSE direction. The light coloured minerals are quartz and feldspar while the dark coloured minerals tend to be biotite and chlorite. Lineation is well marked in schist and strongly deformed in metaconglomerates, where pebbles are set in linear fabric fashion and occurred on the rock surface. 


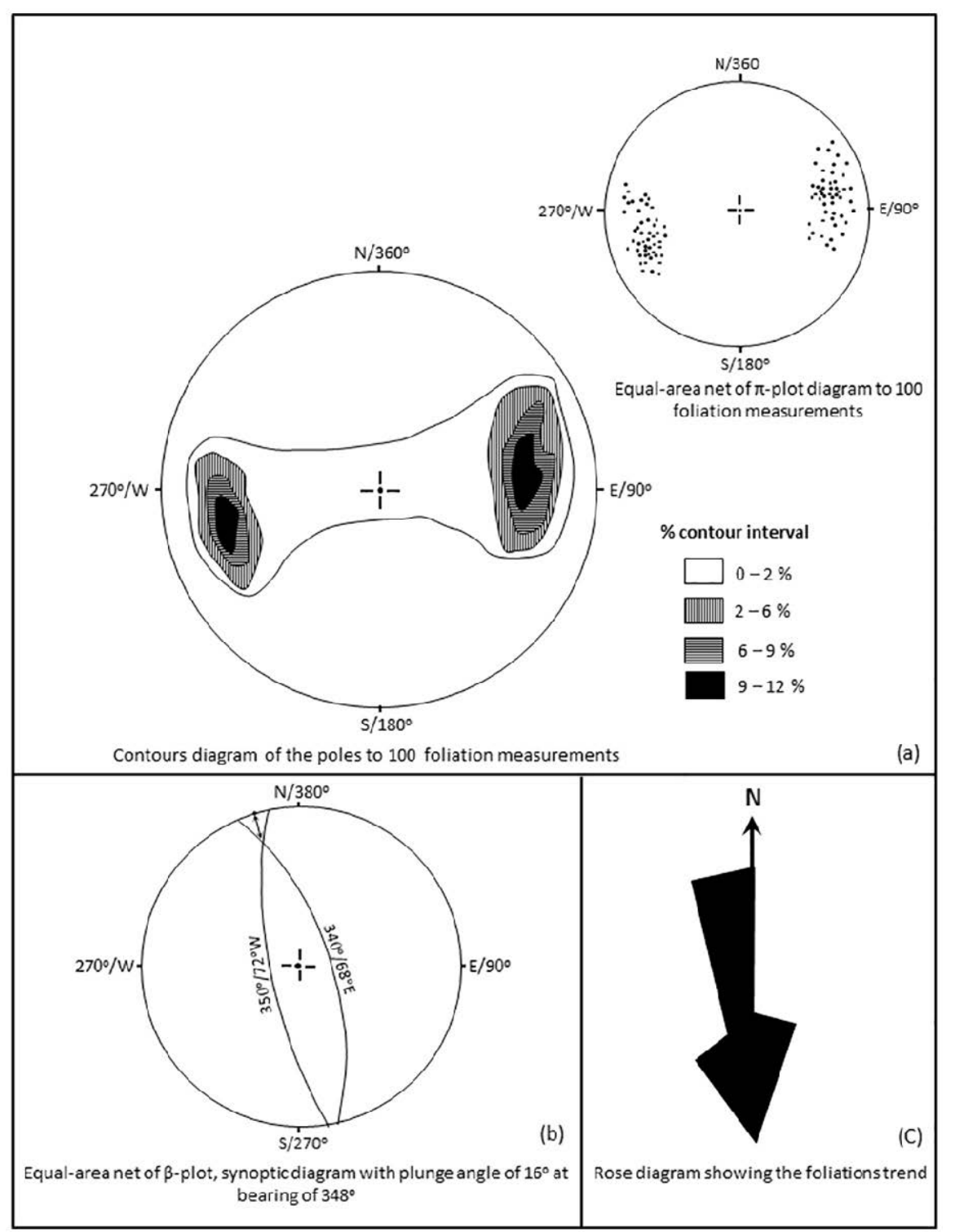

Figure 16: Schist foliation orientation data collected in Igarra and surrounding area, Southwestern Nigeria: (a) Equal-area net of $\pi$-plot and contoured diagram of poles, (b) Equal-area $\beta$-plot and (c) Rose diagram of foliation trend.

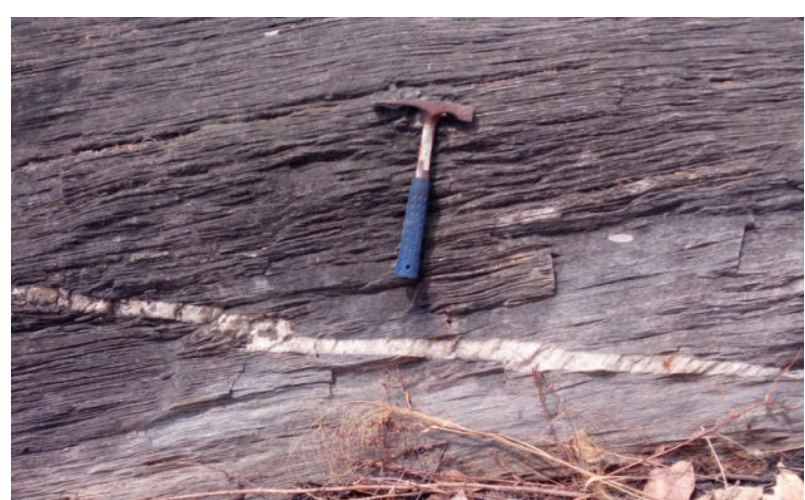

Figure 17: Foliation in Quartz-biotite schist cuts by quartz vein at Ojirami.

\section{Folds}

The strike and dip measurements obtained from the foliated schist outcrops over the entire area define an antiform and synform that is a tight isoclinal fold (Figure 2). Equal-area stereonet plots also revealed that the isoclinal fold plunges at low angle to the north (Figure 16). The $\mathrm{S}_{2}$ foliation that cuts across an earlier $\mathrm{S}_{1}$ shows a uni-polar orientation resulting from SSE-NNW directed stress (Figure 16). In the western part of Igarra, foliation trends north- south, dips westerly at an angle of $60-82^{\circ}$ (Figure 2). To the east of Igarra, the foliation is also north-south trending and dips easterly at an angle of $62-84^{\circ}$ (Figure 2). Minor folds occur as tight to isoclinal parasitic folds on the limb of the major $F_{1}$ fold (Figure 18). 

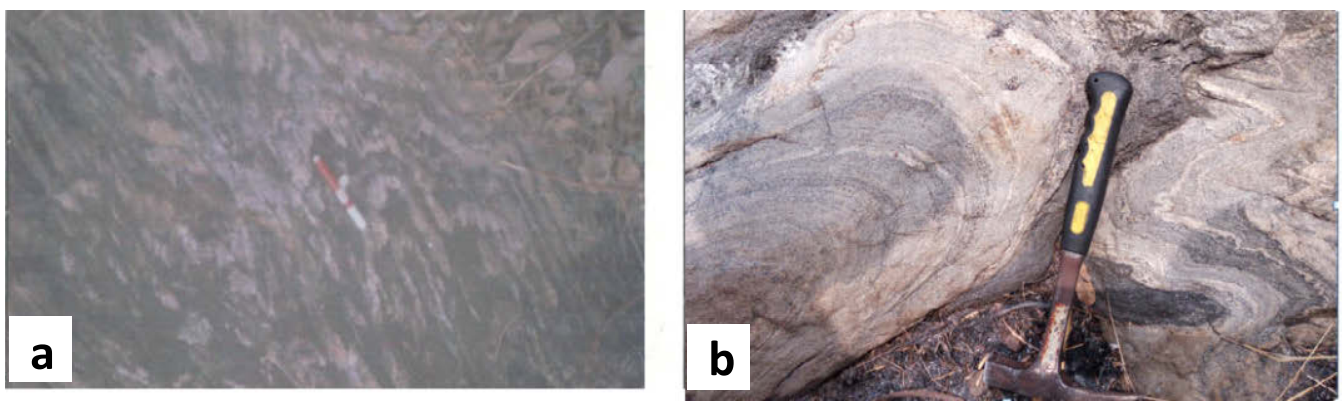

Figure 18: Fold (a) Plunging microfolds on quartz-biotite schist, close to Anglican Cemetery, north of Igarra. (b) Parasitic folds within the schist at Okpe.

\section{Joints}

Joints are the most common secondary structures in the Igarra schist belt. They are very common in both metasediment and the intrusive rock, especially in the porphyritic-granite (Figure 19). Some joints have been filled with quartz of probable hydrothermal origin. Tight $(0-0.1 \mathrm{~cm})$

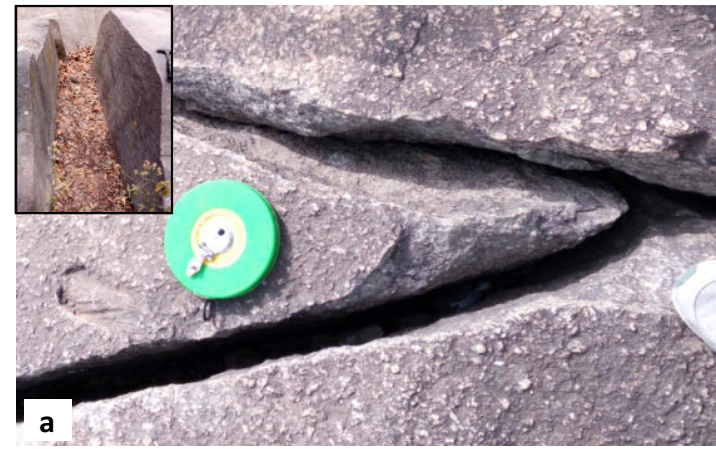

to open $(0.1-30 \mathrm{~cm})$ joints are common in porphyritic-granites (Figure 19a). Joints orientation (among the metasediments) is quite irregular and varies from NE-SW to E-W directions with a few parallel to the penetrative fabric (NNW-SSE) of the metasediments (Figures 11,17 and 19). Joints in the area generally vary in length from $2-15 \mathrm{~m}$.

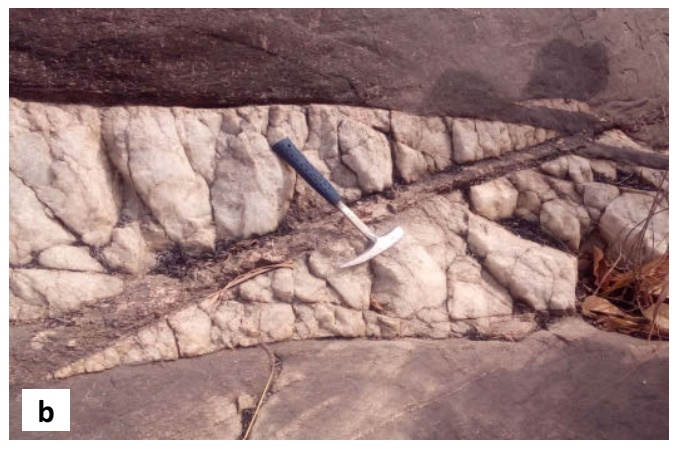

Figure 19: Joints in basement rocks (a) Joint in porphyritic-granite, east of Igarra main junction. Insert, open joint. (b) Joint cuts across quartz-biotite schist fabrics and filled with magmatic residual materials as quartz vein at Semolika.

\section{Metamorphism}

The mineral assemblages in the metasediments were used to define the intensity of metamorphism in the schist belt. The petrographic study shows that metamorphism ranges from green schist to amphibolites facies. The amphibolites facies is defined by the presence of hornblende + biotite + plagioclase + quartz in quartz-biotite schist while the green schist facies is defined by the presence of chlorite + quartz + epidote \pm actinolite in metaconglomerate and calc-silicate gneiss (Figures 4, 6 and 9). Suggesting low to medium pressure (Buccan-Barrovian) metamorphism grade (Winkler, 1979). This view is in agreement with previous studies around the Basement complex of the Southwest Nigerian (e.g. Hockey et al., 1986; Rahaman, 1988; Annor, 1998).

\section{Structural/Evolutionary Model}

The metasediments retain relics of their parental heritage such as chemical composition and bedding $\left(\mathrm{S}_{\mathrm{o}}\right)$. That being the case, the protoliths (probable thick sedimentary pile of fine clastic materials) of the metasediments were laid down horizontally (bedding) prior to metamorphism. Elevated temperatures and compressive stress led to partial melting, recrystallisation, folding and metamorphism of the protoliths during subsequent orogenic events. The process of recrystallisation occurred under the horizontally directed stresses and typically developed a foliation which is perpendicular to the stress $\left(\mathrm{S}_{1}\right)$ (Figure 20). During this deformation episode the primary sedimentary structural features $\left(\mathrm{S}_{\mathrm{o}}\right)$ are not completely destroyed. 


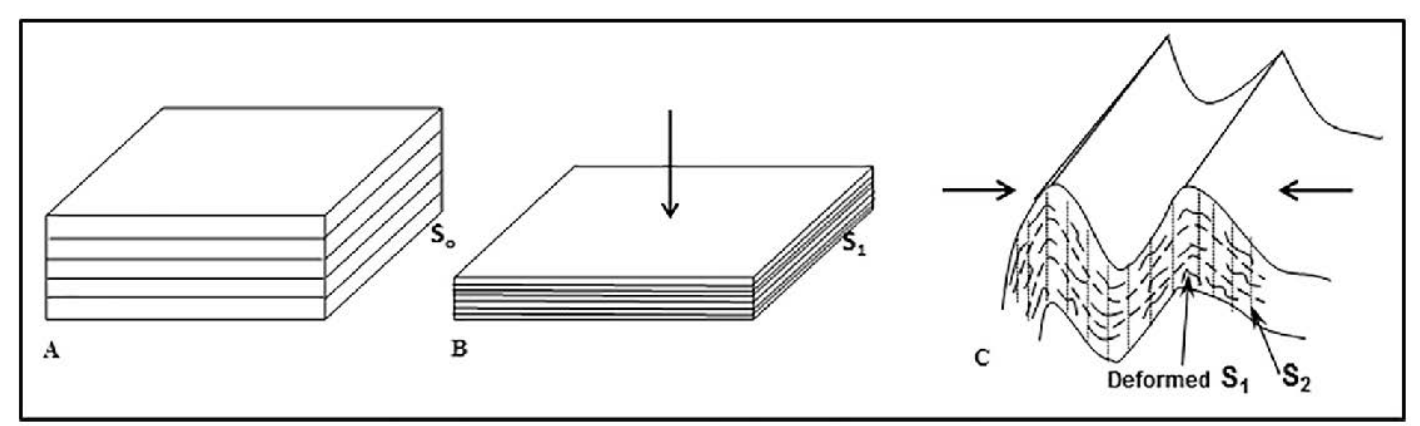

Figure 20: Simplified sketch of the structural model of the metasediments in Igarra and surrounding areas, Southwestern Nigeria. (A) Original sedimentary layer $\left(S_{o}\right)$. (B) The deformation of $S_{0}$ to $S_{1}$ as a result of gravitational stress, $S_{1}$ is parallel to $S_{o}$. (C) The formation of $S_{2}$ is then formed as a result of horizontal compression.

The continent was migmatite-gneiss complex in the Archean time (Ajibade, 1989; Dada, 1998). During the Archean, tectonic activities occurred which resulted in the continent forming northsoutherly fractures (Figure 21A). The stretching and thinning of the fractures developed into horst and graben within the basement. The sediments derived from the continent due to the weathering and erosion of the continent, were deposited in the graben (basin). Sequel to sediments deposition, subsidence occurred that led to $\mathrm{S}_{\text {。 }}$ (Figure 21B). Stretching and thinning of the basin alongside with subsidence, accompanied by compressional stress resulted in the formation of $\mathrm{S}_{1}$ foliation accompanied by the $\mathrm{M}_{1}$ metamorphism (Figure 21C), during the Eburnean event in Paleoproteozoic (Grant et al., 1970; Rahaman, et al., 1983; Annor and Freeth, 1985; Annor, 1998).

Another tectonic episode occurred during the Neo-proterozoic time during which, horizontal compression forces acted along the E-W axis on the basin. The force pushed the sedimentary pile together to form the $\mathrm{S}_{2}$ foliation alongside with $\mathrm{F}$ folding (Figure 21D) and the resultant fabric formed is perpendicular to the direction of force. The planar fabric $S_{1}$ is folded into isoclinals-tight $F_{1}$ fold which is refolded into tight-open $F_{2}$ fold and truncated by axial plane cleavage $\mathrm{S}_{2}$ (Annor, 1998). This episode was accompanied by $\mathrm{M}_{2}$ metamorphism and later followed by crustal melting and the intrusion of Pan-African granitoids. These granitoids were emplaced as elongated and parallel bodies to the prevailing trend (nearly N-S) of the strike of the metasediment (Figure 2 and 18), depicting that although the main period of tectonism was over, but its effects were still being felt.

The tectonic regime was capped by upliftment accompanied by the release of lithostatic pressure on exhumation, which led to formation of exfoliation, fractures and joints in most part of Igarra schist belt. The metasediments are lowlying, while the granitoids tend to form the high topographic feature because of their relative resistance to weathering (Figure 21E). The metasediments are concordantly inter-banded, the marble/calc-silicate gneiss, quartzite, and metaconglomerate occur within the enveloped surface of the quartz-biotite schist (Figures 2). 


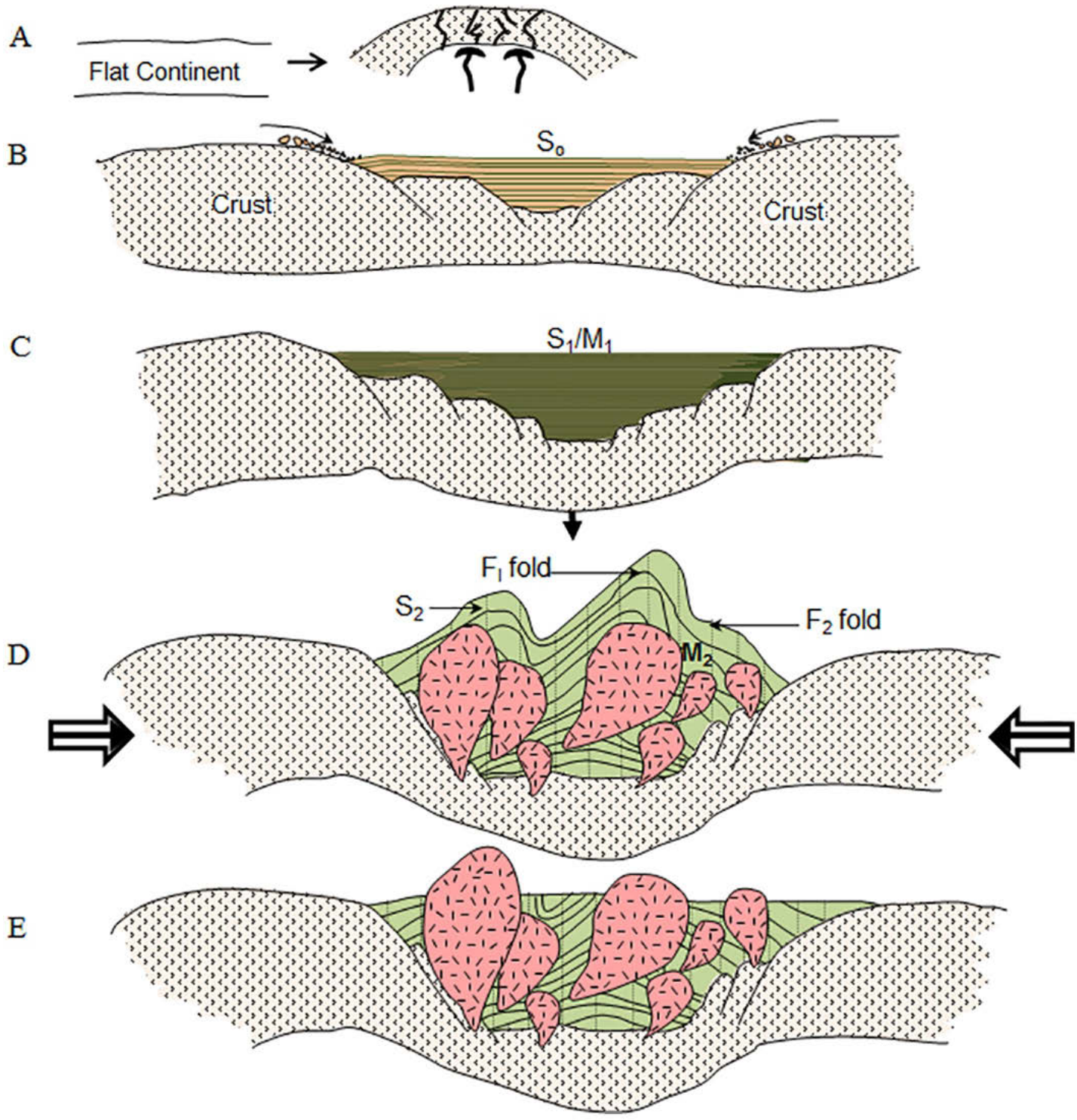

Figure 21: Idealized evolution of rocks in Igarra and surrounding areas, Southwestern Nigeria. (A) Initial flat terrain, doming and pre-rifting which produced N-S fracture. (B) Rifting, deposition and sedimentation (during Archean). (C) Thinning and stretching during subsidence (during Paleoproterozoic). (D) Horizontal compression and plutonism (Pan-African). (E) Weathering and erosion to the present terrain.

\section{CONCLUSION}

The exposed rock types of the Igarra schist belt are classified into two suites of rocks, namely the metasediments and the intrusives. The metasediment comprises of quartz-biotite schist, quartz-sericite schist, marble, calc-silicate gneiss, quartzite and metaconglomerate that are concordantly interbanded. The intrusive comprises of the porphyritic-granite, aplitepegmatite and syenite. The major structures in this area are folds characterised by joints filled by subsidiary intrusions, as quartz vein. The earliest planar metamorphic fabric is succeeded by two folds (tight-isoclinal folds and broad crescent fold) phase with predominantly NNE-SSE (nearly N-S) axial plane foliation. The metamorphic imprints of the schist belt ranges from green schist to amphibolites facies. The metasediments are products of sedimentary piles that were metamorphosed from the impact of tectonic activities, accompanied by magmatic intrusion that truncated the piles and afterward, erosion and weathering wearing them down to the present reliefs.

\section{ACKNOWLEDGEMENTS}

The first and second authors of this paper wish to 
acknowledge Prof. A.E. Annor of blessed memory for knowledge imparted and shared in the area of field geology. Our special thanks go to anonymous reviewers and editors of this journal for their constructive comments and suggestions, which have greatly improved the paper manuscript.

\section{REFERENCES}

Ajibade, A.C. Rahaman, M A and Woakes, M., 1987. Proterozoic lithospheric evolution (Kroner Ed). American Geophysical Union 17, 259-271.

Ajibade, A.C., Woakes, M. and Rahaman, M.A, 1989. Proterozoic crustal development in the Pan-African regime of Nigeria. In: Kogbe, C.A (Ed.), Geology of Nigeria, Rock View, Jos, 57-69.

Annor, A.E. and Freeth, S.J., 1985. Thermotectonic evolution of the basement complex around Okene, Nigeria, with special reference to deformation mechanism, Precambrian Res. 28, 269-281.

Annor, A.E., 1995. U-Pb Zircon age of KabbaOkene granodiorite gneiss: Implication for Nigeria's basement chronology, Geoscience Reviews 2, 101-105.

Annor, A.E, Olobaniyi, S.B. and Mucke, A., 1996. A note on the geology of Isanlu area, in the Egbe-Isanlu schist belt SW Nigeria, Jour. Mining Geology 32, 47-51.

Annor, A.E., 1998. Structural and chronological relationship between the low grade Igarra schist and adjoining Okene MigmatiteGneiss terrain in the Precambrian exposure of Southwestern Nigeria. Journ. Mining and Geology 34, 197-194.

Boesse, S. and Ocan, O., 1992. Geology and evolution of the Ife-Ilesha Schist belt, southwestern Nigeria, In Benin-Nigeria Geotraverse, International Meeting on the Proterozoic Geology and Tectonics of High Grade Terrain, IGCP 215, 123-129.

Dada, S.S., Briqueu, K.L., and Birk, J.L., 1998. Primodial crustal growth in northern Nigeria. Preliminary Rb-Sr and Sm-Nd constraints from Kaduna migmatite gneiss complex. Journ. Mining and Geology, 34, 1-6.

Grant, N.K., 1970. The geochronology of Precambrian basement rocks from Ibadan southwestern Nigeria. Earth Planet Sci. Lett., 10, 28-38.

Hockey, R.D., Sacchi, R., de Graaff, W.P.F.H. and Muotoh, E.O.G., 1986. The geology of Lokoja-Auchi area. Explanation of 1:250,000 Sheet 62, Geological Survey of Nigeria Publication, Bull. 39, 71p.

Holt, R.W., 1982. The geotectonic evolution of the Anka belt in the Precambrian basement complex of Northwestern Nigeria. Unpublished Ph.D. Thesis, The Open University.

Imeokparia, E.G., and Emofurieta, W.O., 1991. Protoliths and petrogenesis of Precambrian gneisses fron the Igbeti area, SW Nigeria. Geochemical Journ., Chem. Erde 51,337-347.

Mccurry, P., 1989. A general review of the geology of the Precambrian to Lower Paleozoic rocks of Northern Nigeria. In: Kogbe, C.A. (Ed.), Geology of Nigeria, Rock View, Jos, 13-37.

Odeyemi, I.B., 1976. Preliminary reports on the field relationship of the basement complex rocks around Igarra, Midwest Nigeria. In: Kogbe, C.A. (Ed.). Geology of Nigeria, Rock View, Jos, 57-63.

Odeyemi, I.B., 1988. Lithostratigraphic and structural relationships of the upper Precambrian metasediments in Igarra area, Western Nigeria. In: Oluyide, P.O., Mbonu, W.C., Ogezi, A.E., Egbnike, I.G., Ajibade, A.C., Ana-Umeji, A.C., (Eds), Precambrian geology of Nigeria, Geological Survey of Nigeria Publication, Kaduna, 111-123.

Ogezi, A.E.O., 1977. Geochemistry and geochronology of basement rocks from NW Nigeria. Ph.D. Thesis, Leeds University.

Okeke, P. O. and Meju, M.A. 1985. Chemical evidence for the sedimentary origin supracrustal rocks, Southwest, Nigeria. 
Journ. Mining and geology 22 (1 and 2), 97104.

Olobaniyi, S.B., 2003. Geochemistry of Semipelitic Schist of Isanlu Area, S.W Nigeria: Implication for the geodynamic evolution of the Egbe-lsanlu Schist belt. Global Journ. Geological Science 1 (2), 113-127.

Oyinloye, A.O., 2006. Metallogenesis of the lode gold deposits in Ilesha area of Southwestern Nigeria: inferences from lead isotope systematic, Pak. Journ. Sci. Ind. Res., 49 (11), 1-11.

Rahaman, M.A., Emofurieta, W.O. and CaenVachette, M., 1983. The potassic granites of Igbeti area: Further evidence for the Pan-African belt in southwestern Nigeria. Precambrian Res., 22, 75-92.

Rahaman, M.A., 1988. Recent advances in the study of the basement complex of Nigeria. In: Oluyide, P.O., Mbonu, W.C., Ogezi, A.E., Egbunike, I.G., Ajibade, A.C., and Umeji, A.C., (Eds), Precambrian geology of Nigeria, Geological Survey of Nigeria Publication, Kaduna, 11-43.

Winkler, H.G.F., 1979. Petrogenesis of metamorphic rocks. $5^{\text {th }}$ Ed. Springer Verlag, New York, 23-237. 